\title{
REVISITING QUALITY TELEVISION: AUDIENCE PERCEPTIONS
}

\author{
Alberto Bayo-Moriones \\ (corresponding author) \\ Professor of Management \\ Department of Business Administration, School of Business and Economics and \\ INARBE \\ Universidad Pública de Navarra \\ Campus de Arrosadía, 31006 Pamplona (Spain) \\ 34948169377 \\ abayom@unavarra.es \\ Cristina Etayo* \\ Senior Lecturer of Media Management \\ Department of Media Management, School of Communication \\ Universidad de Navarra \\ Campus Universitario, 31080 Pamplona (Spain) \\ 34948425600 (ext 2097) \\ cetayo@unav.es
}

\author{
Alfonso Sánchez-Tabernero \\ President of the University \\ Professor of Media Management \\ Department of Media Management, School of Communication \\ Universidad de Navarra \\ Campus Universitario, 31080 Pamplona (Spain) \\ 34948425600 (ext 2218) \\ astabernero@unav.es
}

This is an accepted manuscript of an article published by Taylor \& Francis in International Journal on Media Management, vol. 20, 2018, issue 3 on 8 Nov 2018, available online:

https://doi.org/10.1080/14241277.2018.1538146

\footnotetext{
* The second and third authors acknowledge the financial help provided by the Spanish Ministry of Science and Innovation (CSO2015-64615-R).
} 
Alberto Bayo-Moriones is Professor of Management at the Business Administration Department of Universidad Pública de Navarra, where he earned his Ph.D. His main areas of research are human resource management and quality management. His research has been published in journals such as British Journal of Industrial Relations, British Journal of Management, Human Resource Management, Industrial \& Labor Relations Review or International Journal of Human Resource Management.

Cristina Etayo is Lecturer of Media Management at the School of Communication in the University of Navarra (Spain). She develops her research mainly in the area of mass media communication, especially in television advertising. She is currently working in a project on new audiovisual consumption patterns in Europe, where she analyzes the impact of digitalization on media consumption by people and on the media industry.

Alfonso Sánchez-Tabernero is President of the University of Navarra where he teaches Management of Media Companies. He has been professor of Strategy at the Institute for Media and Entertainment (New York), Visiting Fellow at the European Institute for the Media (Düsseldorf) and President of the European Media Management Education Association. He is mainly interested in two research areas: strategies of growth and diversification of media companies, and the concept of media quality. 


\section{REVISITING QUALITY TELEVISION: AUDIENCE PERCEPTIONS}

\section{Abstract}

This paper analyzes what the audience understands by the concept of quality as applied to television channels. This research also examines the influence of the perceived quality of the different programs broadcasted by a channel on the perceived quality of the whole channel. The empirical part is based on the answers provided by a sample of 405 respondents in Spain. The factors found to be associated with the idea of quality television by the audience are somewhat different depending on the method used to assess it, which points to the existence of social desirability bias when asking directly about it. Notwithstanding these differences, entertainment is the characteristic that the audience most consistently associates with the concept of quality in television channels. The results also show that news programs, movies and magazines, and talk shows are the genres with a greatest influence on the assessment of the quality of a television channel by the audience.

\section{Keywords}

Audience, mass media, media content, television

\section{Introduction}

Although the concept of quality television has been widely used and studied, there is still an absence of a commonly accepted definition. There are several reasons that can justify this situation (Owen and Wildman, 1992). Definitions of quality from other industries are difficult to translate into the arena of media because of its intangible nature. This is the case of classical definitions of quality from engineering such as "conformance to requirements" or "number of defects per million opportunities" that have been very influential in quality management (Crosby, 1979). 
Moreover, quality television can be studied from several points of view: managers of media firms, professionals, academics or the audience (Berné-Manero et al., 2013). For example, from the perspective of experts and practitioners, special attention has been paid to the identification of objective ingredients of television quality (Wober, 1990; Leggatt, 1996; Zaller, 2003). From the perspective of viewers, the approach has consisted of identifying quality television with meeting customer expectations (Liu et al., 2004). However, this idea, stressing the relationship with satisfaction of one's own needs and enjoyment, ignores that television is not merely a consumption product generating private benefits, but is also a public service that must pursue social goals (Costera Meijer, 2003).

These difficulties in defining the concept of quality television, especially from the perspective of viewers, have led to a scarcity of empirical studies. Within this context, the goal of this paper is to shed some light on the topic by analyzing a sample of 405 Spanish television viewers. More concretely, we focus on the consideration of the concept of quality television by the audience at the channel level. Our objective is threefold. Firstly, we offer empirical evidence on the answers of the viewers to the question of which factors they associate more to the concept of quality television. Secondly, we focus on the problems related to the measurement of the real opinions of viewers on the topic. Finally, we analyze the relationship between the perceived quality of a channel and that of the programs it broadcasts.

\section{Theoretical background}

\section{Meaning of quality television for viewers}

Quality television is a complex concept and can have different meanings. Our approach to quality is multidimensional, as in the literature assessing television programmes from multiple attributes ( $\mathrm{Lu}$ and Lo, 2007). Next, we will refer in detail to 
these different factors with which quality television has been associated from the point of view of consumers (Bayo-Moriones et al., 2015).

When analyzing the role of public televisions, quality television has been linked to the idea of public service. Therefore, quality has been associated with the fulfilment of the classical triple function of the media: informing, educating and entertaining (Blumler, 1991). When asked, viewers agree to a large extent with these elements as ingredients of what they consider quality television (Ishikawa, 1996).

Regarding the function of information, quality has been associated with the concepts of independence, pluralism, objectivity, veracity, balance, neutrality, rigor and trustworthiness (Aguilar-Paredes et al., 2016; Hampton, 2008; González-Gorosarri, 2017; Patterson, 2000; Westerstahl, 1983).This involves balancing stories with multiple and diverse points of view, a variety of knowledgeable sources and the presence and expression of diverse ideas and ideologies representative of the different segments in society (Wildman and Owen, 1985). This concept of diversity of ideas has also received the name of open diversity (Van der Wurff, 2004), which has been more popular within the realm of media policy, especially in the public sector (Park, 2005) The news should also be relevant and useful in order to understand a complex world (Heinderyckx, 2006).

In the case of the role of entertainment, quality television means that watching it provides viewers with disconnection from problems and unpleasant circumstances, providing relaxation, aesthetic pleasure and emotional release (Tannenbaum, 2014). Entertainment involves holding the interest of the audience, being fun one of the main emotional gratifications (Bartsch, 2012). Therefore, in most cases audience satisfaction or perceived quality happens to be an "entertaining proposal" which the viewer enjoys.

As far as education is concerned, viewers understand quality television as one that, in at least part of its programming, focuses on the arts and sciences, making scientific 
knowledge comprehensible by presenting the latest discoveries and findings, favouring debates on cultural topics, opening people's minds to new ideas and perspectives and enabling the audience to learn about other cultures (Singhal \& Rogers, 2002). Caffarel (2005) underlines that education in current societies does not rest in schools only, but is also nurtured by the contents offered on television. In this line, she suggests that public quality television must contribute to cultural and social education in areas such as health, accident prevention and distance education.

Closely related to this educational role of quality television is the promotion of desirable values (Samaniego \& Pascual, 2007). This goes beyond the transfer of knowledge to viewers but means presenting civic values such as the healthy lifestyles and respect for the environment, and avoiding undesirable contents, such as violence and pornography (Artero et al., 2016). Quality television should promote desirable values, discourage undesirable behaviours, embed the principle of citizenship and generate critical consciousness (Camacho, 2005; Caffarel, 2005; Vila \& Küster, 2014). The evaluation of the quality of a television channel should include not only the analysis of audiences but also its ability to promote values (Caffarel, 2005).

The variety of contents is a dimension very often associated with the quality of a given television channel (McQuail, 1992; Peitz \&Valletti, 2008). Although the concept of diversity applied to television may have different meanings, from the point of view of the audience the most relevant one has to do with the number of different genres included in the programming structure, that is, content diversity (Wildman and Owen, 1985). This vertical diversity is associated with quality because it involves the possibility of meeting the expectations of a wider audience (Gutiérrez, 2000). Moreover, the more diverse the programming of a channel is, the more functions can be fulfilled and more balanced consumption choices are made by viewers (Park, 2005). 
Some authors also include commitment to society as an element of quality television (Heinderyckx, 2006). In order to fulfil this requirement, television should cover events relevant to society, and reflect realities and facts important for the whole population, so that all social segments and minorities are represented (Murschetz, 2002). Quality television should be in contact with the most immediate realities of the population (Caffarel, 2005). A concept related to this idea is diversity as access, referring to the permeability of the media to different voices, groups and social interests (Pujadas and Oliva, 2007). From this approach television quality is not just a matter of the channel and the viewer, but takes into account the interests of a wider range of stakeholders (Artero et al., 2015).

Another dimension of quality television proposed by some authors is originality. For example, Thompson (1997) considers that quality television is not "regular television". In his opinion, the quality in television requires innovation and being different to anything ever seen (Broadcasting Research Unit, 1989). That is, quality television must break rules (Thompson, 1997). Originality and innovation mean discarding the imitation of competitors' programming strategies. Singularity is opposed to the idea of commercial competition and television.

Although technical excellence, associated to taste and aesthetics (Bottomley, 2015), has been considered in the concept of quality television more frequently when analysed from the perspective of professionals such as program creators, members of juries and television reviewers, viewers can also form their own opinion. Although they may lack the expertise to assess this aspect in detail, they have the ability to make general appraisals, detect extremely high and low technical quality and are sensitive to production value when assessing quality (Cummins \& Chambers, 2011). For instance, a large-scale survey among television users in Israel found that although the audience is not very good 
at discerning gradations of production value among different programs and genres, technical characteristics explain television program appreciation and quality evaluations" among viewers (Shamir, 2007). Quality television should not be understood as elitist; it must be appreciated as quality television by the majority of the audience (Camacho, 2005) and this can be achieved with technical quality in formats, ideas, scripts, illumination, sound, scenography, photography and hosts (see, for example, Dhoest, 2014, for dramas, and Guerrero \& Etayo, 2015, for entertainment programs).

The promotion and even the defence of the local culture is another element posed by some authors as proper to quality television (Heynderickx, 2006). In this line, promoting the knowledge of the domestic cultural manifestations and the maintenance of traditions has always been at the core of the public service nature of public televisions, either at the national or regional level. This promotion of local culture is associated to the protection and diffusion of the national language as an objective need and the bet for the national film industry (Caffarel, 2005).

Finally, quality can be understood by the viewers as fulfilling their desires when watching television (Vorderer et al., 2004). Such subjective dimension has been influenced in a relevant way by the new multi-screen universe (Phalen \& Ducey, 2012). This involves a definition of quality as the adjustment to the interests and preferences of the viewers (Del Valle, 2005). Viewers consider a television channel as good quality as long as their needs are met and programmes respond to their tastes (Connolly et al., 2015). From this perspective perceived quality is closely related to audience satisfaction (BayoMoriones et al., 2015; Von-Rimscha et al., 2010). This dimension of quality is general in that it refers not only to the program type but also to the values and opinions conveyed by the channel.

In summary, there are ten potential dimensions of quality television from the point 
of view of the consumers: information, entertainment, education, promotion of desirable values, content variety, commitment to society, originality, technical quality, protection of local culture and adjustment to one's own preferences and opinions.

\section{Measuring the concept of quality television for viewers}

The meaning of quality television for viewers has traditionally been measured by asking them directly about it. The main advantages of this method are its simplicity and straightforwardness. Although the concept of quality television is complex, as explained above, the question is direct and clear and respondents do not find many difficulties in answering it. This approach corresponds to the stated importance method used in the marketing research to measure the relative impact of specific attributes of products on customers' satisfaction with them (Chu, 2002; Kozak, 2001).

However, problems may appear in taking this approach. Measuring the opinions of people so directly might lead to social desirability biases (De Jong et al., 2010; Dalton and Ortegren, 2011), thus the interviewees answer in a way they expect to be viewed more favourably by the interviewer. When they answer questionnaires about quality television, they tend to look for the "right answer", quoting some socially accepted traits or requisites that make them seem educated, cultured, altruistic and sophisticated.

This potential problem makes it advisable to explore the feasibility of other methods to identify the real opinions of people on quality television. The traditional debate around quality television has focused on the contradictions between what people think about quality and how they behave. From this perspective, a suggested proxy for quality opinions could be the patterns of television watching. However, this perspective ignores that perceived quality, preferences and behaviour are different theoretical concepts: a consumer may consider a certain channel as quality television but does not 
like it and, therefore, decide not to watch it. For example, many viewers say that in order to reach high standards, a channel should broadcast balanced documentaries, cultural programs and films from local origin but these genres usually achieve low audience rates (Claussen, 2004).

Therefore, having discarded viewing patterns as an adequate measure for the meaning of quality television for the audience, alternatives are needed. One consists of measuring it indirectly. This is what the marketing research literature has defined as the derived or revealed importance method, which aims to measure the importance of attributes in relative terms (Haber and Lerner, 1999). The logic behind this implicit importance measures is to relate performance at the attribute-level of a product or service to a measure of overall performance (Mikulic et al., 2016; Huang and Sarigöllü, 2008).

This involves performing several steps. Firstly, viewers are asked about their opinion on the overall quality of a given television channel. Secondly, they are requested to assess the channel according to the different dimensions suggested to make up the concept of quality television, such as educational, etc. Thirdly, a correlation analysis between the overall quality measurements and the different quality dimensions is conducted. A positive and high correlation of a dimension with the overall quality measurement indicates that the dimension is very important for the respondents in determining perceived quality. When that correlation is around zero, the result reveals that viewers do not consider that dimension as relevant in their idea of quality. Therefore, this method attempts to reveal the true meaning of quality television for the audience by discovering what happens when they have to apply the concept to the television channels they know.

The quality of a channel as an aggregate 
Another potential approach to analyzing quality lies in considering television channels as a simple set and sequence of programs. For example, Chan-Olmsted and Kim (2002) highlight that programming has a large influence on viewer perception of the quality of the television channel, as compared to aspects such as advertising and corporate communication actions. Therefore, the overall perception of the channel would be the result of the aggregation of the perceptions about the different individual programs or genres broadcasted. In this formative approach, the channel itself would not provide any positive (or even negative) value in terms of quality to the programs contained in it.

The question that emerges is how the individual perceptions of quality of the programs are aggregated in order to obtain the overall score. Obviously, the simplest way to do so would be by computing the average. However, it does not seem reasonable to consider that, when evaluating the quality of a channel, viewers assign the same importance to all programs. Genre preference, defined as television viewers' predisposed liking of one specific program genre among a set of available program types, has been found to be an important predictor in viewing choices, behaviours and attitudes (Guo and Chan-Olmsted, 2015).

These differences could be related to several factors. One of them is the importance of the program or genre in the scheduling. If a genre occupies a large proportion of the broadcasting time of the channel, it should have a great influence in how viewers perceive that channel.

The same would apply when considering the popularity of the genre. It is not only broadcasting time, but also how many people watch the genre which has an impact on the global assessment of the channel. When analyzed for the whole audience, the best-known and most frequently watched programs should be more influential in determining the overall perception of quality. 
Another important issue at this point is the ability of a television company to create programs which are different from those offered by the competition. Whereas there are genres where it is difficult to generate distinctive approaches or which can be easily imitated by competitors, there are others that are crucial in defining the identity of television channels. For example, Ahlers (2006) argues that news programs may generate strong links with the audience, constituting an effective barrier against replacement or competition from other channels. This might explain why important resources are invested in news programs, in spite of their being difficult to recover during such programs' advertising breaks (Chan-Olmsted \& Kim, 2001). Consequently, the perceived quality of news programs should have a stronger effect on the perceived quality of the channel as a whole than other television genres. The opposite may occur with movies: the viewer may understand that the channel is only responsible for broadcasting them but not for producing them.

\section{Research questions}

As a summary, the following research questions are addressed empirically in the next section:

RQ1. What are the factors most associated with quality television by viewers?

RQ2. When analyzing how the audience ranks the importance of the different dimensions of quality television, do the direct method and the indirect procedure provide the same results?

RQ3. Which genres are most influential in the overall perceived quality of a television channel?

\section{Methods}




\section{The Spanish television market}

The Spanish television market has evolved from the public monopoly (until 1990) to an oligopoly with a broad variety of local, regional and national television channels. The economic crisis was particularly harmful for the advertising industry: television advertising expenditure decreased from $3.468 \mathrm{M} €$ in 2007 to $1.703 \mathrm{M} €$ in 2013 (InfoAdex, 2015). Such a deep and lasting crisis, together with the consequences of the analogue switch-off, fostered some concentration operations after 2012. The high fixed costs needed to preserve digital licenses were joined by the increasing fragmentation of the audience, the threats of pay television and an increase in the price of the most desirable contents, such as sports (García-Santamaría et al., 2014).

As a result, several channels failed and two big audiovisual groups emerged: the Italian owned Gestevisión and Atresmedia. In 2014, together they accounted for $58.4 \%$ of the audience and $86.3 \%$ of the advertising television market (Kantar Media, 2015). There has been a clear displacement of advertising in conventional media towards these large mainstream channels because of their territorial control and high audience levels (García-Santamaría et al., 2014). In that year, Gestevisión owned six national channels which accounted for 30.7 per cent of the Spanish television audience. Five channels belonged to Atresmedia; their combined audience market share was 27.7 per cent. The public corporation RTVE has two national channels (16.7 per cent of the audience). Other groups had market shares below four per cent.

Each of the three big players has a general-content leading channel: Telecinco (owned by Gestevisión) reached 14.5 per cent of the audience in 2014, while Antena 3 (Atresmedia) had 13.6 per cent, and TVE1 (RTVE) was third, with 10 per cent (Kantar Media, 2015). There are some differences among the channels' programming strategies: Telecinco broadcasts many reality shows and contests and its news programs are more 
left-wing. The main bets of Antena 3 are drama and movies and it is more right-wing. TVE1 has more cultural and news contents and does not have advertising.

The launching of new channels during the last fifteen years has fostered an increase in television consumption in Spain: from 210 minutes per person in 1998 to 235 minutes in 2010 and 238 minutes in 2014 (Kantar Media, 2015). Such an increase over the last few years may be the result of another factor: the crisis; in some way, the audience of commercial television is countercyclical.

\section{Sample}

Since we focus on the perception of quality television by consumers, our unit of analysis is the television viewer. Since almost everyone is a consumer of television, the population of television viewers can be identified with the whole population. Confirming this assumption, a study conducted by Kantar Media (2013) reported that $98.2 \%$ of people living in Spain had watched television at least one minute in the last month. In our study we will restrict the population to individuals over 14 years old to guarantee their understanding of the questions in the survey.

For the purpose of data collection, a questionnaire was developed by the authors. The first set of questions investigated the socioeconomic and demographic profile of the respondents. The second part was made up of several questions related to television consumption and preferences patterns. Finally, the last part included several questions requiring the assessment of the dimensions of quality television explained in the previous section for Antena 3.

Taking into account the characteristics and evolution of the Spanish television market described above, there were several reasons that led us to choose Antena 3 as the subject of our analysis. A group of them have to do with the knowledge of the channel by 
potential respondents and their ability to answer questions included in the questionnaire. In order to get reliable responses, the selection of a channel well-known by the audience was needed. Several reasons made Antena 3 an adequate option from this perspective. Firstly, it is one of the three channels in Spain with higher audience rates, together with Telecinco and TVE1. Secondly, it is one of the two oldest private television channels in Spain, together with Tele 5, which increases the audience's familiarity with them. Thirdly, the programming strategy of the channel has remained stable throughout the years, what makes Antena 3 a channel whose main and distinctive features can be easily identified by the audience.

There were other reasons that justified this choice. Antena 3 is a private channel, therefore free from the constraints and labels usually placed on public channels regarding quality and public service. The evaluation of public channels by the audience might be subject to bias derived from social desirability. Furthermore, there is variation among the audience on the perception of its quality. Whereas Tele 5 is generally regarded by most viewers as a low-quality product, there is more diversity of opinions about Antena 3. This variation in the dependent variable is necessary when estimating empirical models. In the study by Centro de Investigaciones Sociológicas (2010), 8.17\% of the respondents considered Antena 3 as a very good quality channel; $39.46 \%$ as good quality; $42.58 \%$ as poor quality and $9.78 \%$ as very poor quality. The percentages for Telecinco were $6.20 \%$, $29.38 \%, 38.25 \%$ and $26.18 \%$ respectively.

A sample of 418 respondents was obtained from the population living in Navarra, a region in Northern Spain. The sampling method was quota sampling. The subgroups used to define the quotas were sex and age intervals. The proportions by sex and age intervals in the sample are not statistically different to the proportions in the population. The collection of the information was made through face-to-face interviews with the 
respondents. In order to ensure that our respondents were Antena 3 viewers a filter question was used. This question asked the respondents how frequently they watched Antena 3. If the answer was never or almost never, they were considered not suitable to answer the items related to the quality of the channel. 418 respondents started to answer the questionnaire and 13 indicated that they never or almost never watched Antena 3 and, therefore, are not considered in the analysis because of their lack of knowledge of the channel. Among the final respondents, $48.6 \%$ were men and $51.4 \%$ women. $17.1 \%$ were between 14 and 24 years old; $35.9 \%$ between 25 and $44 ; 27.2 \%$ between 45 and 64 , and $19.8 \%$ were 65 or older.

\section{Measures}

Meaning of quality television. Respondents were asked about the characteristics that in their opinion best define quality television. They were provided with the ten definitions explained in the theoretical section of the paper: informative, entertaining, educational, the values it conveys are desirably varied in contents, committed to society, original, of good technical quality, protective of Spanish culture and fit in with my preferences and opinions. They were requested to rank them, so that the score was 10 for the most important aspect, 9 for the second most important and so forth until 1 for the least important. Forcing respondents to make trade-offs among attributes provides more valid measures than requesting an absolute assessment of the importance (Chrzan and Golovashkina, 2006).

Quality assessment of the television channel. Interviewees were asked to evaluate the quality of Antena 3 through a 5-point Likert scale (1-very poor; 5-very good). 2\% of the respondents answered the quality was very poor, $7.6 \%$ poor, $30.1 \%$ medium, $41.3 \%$ good and $19 \%$ very good. This measure is very similar to other measures used in the 
literature to the assessment of the quality of television channels by viewers (Vallejo \& Villena, 2015).

Assessment of factors associated with the quality of the channel. Respondents were asked to indicate their agreement or disagreement on a 5-point Likert scale (1-strongly disagree; 5-strongly agree) with a series of statements on Antena 3. These items were intended to capture the opinions of viewers regarding the ten dimensions associated with quality television. We have developed the items from the conceptualization of the dimensions presented in the theoretical section. Exploratory factor analyses with varimax rotation were conducted for the items aimed at measuring each of the ten factors, ensuring that all items displayed significant loadings in the same factor. These involved dropping 9 of the 65 original items. To ensure that the items used to operationalize the constructs were internally consistent, reliability analysis was carried out using Cronbach's alpha. These reliability coefficients are higher than the recommended level of 0.70 in all cases (see Table 1). Additive indices were computed for each factor.

\section{INSERT TABLE 1 ABOUT HERE}

Quality assessment of the different genres on the television channel. Interviewees were asked to evaluate the quality of the different program genres on Antena 3 through a 5-point Likert scale (1-very poor; 5-very good). They were provided with some examples of names of current and recent programs for each genre in order to facilitate the answer. The respondents were asked about twelve genres: news; magazines and talk shows; movies; fiction television series; game shows; sports; documentaries; reality television; music and talent search; entertainment and humour; divulgatives; and docufiction.

\section{Procedure}


The direct analysis of the opinions of viewers on the meaning of quality television will be based in the frequency distribution of their responses. Wilcoxon tests will be conducted to study whether there are significant differences in their average position in the ranking made by viewers.

In order to capture the factors associated with quality television in an indirect way, an ordinary least squares model where the dependent variable is the quality assessment of the television channel and the independent variables are the assessment of the factors associated with the quality of the channel has been estimated. Given the ordinal nature of the dependent variable, an ordered logit model has been estimated to check that the results are robust to the econometric specification. The same procedure will be used to test the influence of the perceived quality of the different genres on the perceived quality of the whole channel.

\section{Results}

Table 2 displays the frequency distribution of the answers to the request to rank ten factors according to their importance in defining quality television for the viewer. When asked about the most important factor, the most frequent answer was that quality television must inform well and be neutral $(28.6 \%)$, followed by it must entertain (18\%), it must educate (11.4\%) and must adjust to my preferences and opinions and promote desirable values (10.71\%). The least chosen options were it must be of good technical quality $(1.5 \%)$, protect Spanish culture $(2 \%)$, be varied in contents $(4.7 \%)$, committed to society $(5.9 \%)$ and original $(6.4 \%)$.

\section{INSERT TABLE 2 ABOUT HERE}

Looking at the answers to the question on the least important dimension, the results are as follows. The options chosen most frequently are protection of Spanish culture 
(26.9\%), good technical quality (22.2\%) and adjustment to my preferences and opinions $(20.2 \%)$. These are followed by varied in contents $(6.9 \%)$, committed to society $(6.4 \%)$, conveys desirable values $(5.9 \%)$, original $(4.9 \%)$, educational and entertaining $(2.2 \%)$ and informative (2\%).

Finally, in the last row the mean for the place order in the ranking is displayed. According to this, good information and neutrality are the most important dimensions, since the average value is the highest (7.291). It is followed by entertaining (6.746), educational (6.486), conveys desirable values (5.844) and original (5.696). In mid-low positions we can find committed to society (5.422) and varied in contents (5.235). Finally, adjustment to my preferences and opinions (4.830), technical quality (3.852) and protective of Spanish culture (3.598) show the lowest mean scores.

The results of the Wilcoxon tests conducted to check whether there are statistically significant differences between the dimensions in their medians indicate that the differences in the scores in the last row in Table 2 are significant in all comparisons except for four pairs: entertaining - educational; conveys desirable values - original; conveys desirable values - committed to society and original - committed to society.

Therefore, independently of how we analyze the answers to the direct question on how television quality is defined, the results are quite consistent. Informative is the dimension most identified with quality television, followed by entertaining and educational. The least relevant dimensions are variety in contents, adjustment to own preferences and opinions, good technical quality and protective of local (in this case Spanish) culture.

Indirect measure of factors associated with quality television by viewers. Table 3 includes the results of the models analyzing the influence of the assessment of different aspects of the channel on the evaluation of its quality by the viewer. The first column displays the 
results of the ordinary least squares analysis, whereas the second column shows the results of the ordered logit models.

\section{INSERT TABLE 3ABOUT HERE}

Regarding the statistical significance of the independent variables, we can see that there are no differences between the two models, which indicates robustness in the results independently of the econometric estimation technique.

Four dependent variables emerge as significant. The variable with the lowest significance $(p<0.10$ in the ordered logit model and $p<0.05$ in the OLS model) is that assessing the originality of the channel. Our results indicate that the more original the viewer perceives Antena 3, the more quality she attributes to the channel. The three remaining significant independent variables are those measuring whether the respondent considers the channel is varied in contents $(\mathrm{p}<0.05)$, entertaining $(\mathrm{p}<0.01)$ and adjustment to own preferences and opinions $(\mathrm{p}<0.01)$. The sign of the coefficients of the three variables is positive. Therefore, the more entertaining a viewer finds a channel, the more quality she thinks it has. This also occurs with variety in contents. Moreover, when the viewer perceives that a channel coincides with her genre preferences, opinions and values, she considers it of greater quality. The remaining six independent variables are nonsignificant in the two models.

Although there are pairs formed by the coefficient of a significant variable and the coefficient of a non-significant one where the test of equality of coefficients cannot be rejected, these results lead to quite a clear ranking of the factors with which viewers associate quality television.

If we compare this ranking with the ordination obtained when asking the viewer directly about the meaning of quality television, we can find some similarities and many dissimilarities. Entertaining is a highly valued attribute independently of the approach 
used. The same happens with originality, which occupies a middle position in both cases. In addition, the protection of Spanish culture is clearly the least considered factor in defining quality in the two approaches.

However, for the remaining dimensions there are some relevant differences in the position they occupy in both rankings. Among the dimensions that are most valued in the stated importance approach we can find: informative, educative, desirable values and commitment to society. In the opposite situation, there are: technical quality, program variety and an offer coincident with the viewer preferences and values.

The influence of perceived quality of genres on the perceived quality of the whole channel. Table 4 reports the results of the estimations analyzing the influence of the perceived quality of twelve genres of Antena 3 programs on the assessment of the overall quality of the channel. As in Table 4, the first column shows the results of the ordinary least squares model, whereas the second column shows those of the ordered logit model.

\section{INSERT TABLE 4 ABOUT HERE}

Empirical models in Table 4 clearly show that news programs are those whose perceived quality has the largest impact on the perceived quality of Antena 3. The next genre in importance is sports. The other four genres for which a positive and significant relationship has been detected are reality shows, movies, magazines and talk shows and, to a minor extent, game shows. The perceived quality of fiction television series, documentaries, music and talent search, entertainment and humour, divulgatives and docufiction does not seem to influence the overall perceived quality of the channel.

\section{Conclusions}

In this paper we have empirically investigated the concept of quality television from the perspective of viewers. More specifically, we have focused on three goals. First, we have 
analyzed the response of the viewers to the direct question on what they think quality television is. This has led to a ranking of the factors that the viewer associates to a greater extent with television quality. Next we have analyzed whether this ordination remains the same when identifying these factors indirectly. Finally, we have studied the association between the perceived quality of different genres in a channel and the perceived overall quality of the channel. The need of a better understanding of the meaning of quality for viewers comes from its influence on the attitudes and behaviours of the audience (BernéManero et al., 2013; Jardine et al., 2016) and its positive impact on the corporate credibility of television channels, especially for private ones (Vila and Küster, 2014).

According to our results, when asked directly, viewers associate quality television mainly with the three classical three functions of media: they must inform, entertain and educate. However, an indirect analysis of the issue reveals that the most important aspects are not identical. Whereas entertainment remains as a relevant dimension, the same does not occur with informative and educational. In fact, adjustment to own preferences and opinions, variety of contents and originality appear as dimensions that are important for the audience when assessing the quality of a television channel.

Our paper has also shown that the perceived quality of a given television channel is highly associated with the perceived quality of its news programs and, to a lesser extent, with that of magazines and talk shows, movies, sports and reality television. This result indicates that it is not only the broadcasting time that determines the importance of a genre in the overall assessment of the channel. For example, in the channel analyzed, Antena 3, sports accounted only for the $1.96 \%$ of the overall broadcasting time but has been found to be the second most relevant genre (Kantar Media, 2015).

Our results have important implications for the academic study of the concept of quality television for the audience. Although many dimensions have been proposed for 
inclusion in the concept of quality television, our findings indicate that not all of them are equally important for the viewers. In fact, some are quite marginal among the audience. Therefore, our results enable us to more narrowly delimitate what quality television means for consumers.

Another important contribution is that, when defining quality television, there are important differences between what people say and what applications of the concept to television channels reveal they think. This implies that social desirability concerns play an important role when dealing with this issue through direct questions, which adds complexity to the measurement of an already complex concept.

These findings have several main managerial implications. Managers and programmers should be aware that how the questions are formulated to the audience may affect the answer; audience surveys should avoid the "distortion effect" of political correctness. In other words, the right context and the right approach may be vital to better understand the audiences' preferences and perceptions of quality. This fact is of increasing importance, considering the arrival of new competitors, both traditional new channels and new substitutes like Netflix, Amazon Prime, Hulu, YouTube or Apple TV.

The development of such over the top (OTT) and subscription video on demand (SVOD) services has changed the rules of the market: the old oligopolistic model was based on getting enough viewers to maximize advertising income; but in the new scenario every provider of audio-visual contents should pay more attention to the level of satisfaction of the audience in order to decrease the "risk of escape" of viewers towards the offers of new rivals. In other words, there are more providers of audiovisual contents and all of them try to capture a target which is quite fixed: the time of the audience.

Pay services like Netflix, Amazon Prime, HBO Now or Hulu basically sell "expectations": they are able to get new subscribers if potential customers consider that 
they will get unique and attractive contents. Those SVOD and OTT services invest in quality entertainment programs in order to get new subscribers in the short term: viewers who are interested in a particular show or sport championships decide to pay the subscription. But such strategy has also a positive side effect: the brand's appeal grows and attracts new customers in the long term because more people trust in the brand.

Managers and programmers should consider that each piece of content has two effects: on the one hand, they are able to attract viewers (Berné-Manero et al., 2013 and Vila \& Küster, 2014) and, as a consequence, advertisers; but, in addition, a less obvious consequence is that some programs have a "halo effect": their reputation is transmitted to the whole channel. Therefore, it may make sense to broadcast a program which is not profitable per se if it can increase the perception of quality of the whole brand.

This is the case for news programs, which are expensive to produce. In some way, the total cost of news should not be considered as a pure expense but also as an investment which may be recovered in the long term, as a consequence of the brand's increased value. Although the investment in any television content is always positive, our findings emphasize that it is in news programs where the effort should be larger in order to improve the perceived quality of the channel. In this line, the literature on news quality underlined aspects such as the use of complex structures in the elaboration of news and the prevalence of hard news treated as hard news (Patterson, 2000).

SVODs and OTT services usually do not broadcast news, but they may apply the suggested accounting principle to other contents which may produce a similar "halo effect". In fact, some "hybrid offers" -like documentaries, docufiction, sport and cultural programs- which mix information and entertainment, have this strong influence in the value of the brand. 
Our results on the perceptions the audience about television quality bring some additional implications for conventional channels and especially for Antena 3, which has been the channel subject to analysis. The findings of the paper highlight the benefits of being perceived by the audience as a varied, original and, most importantly, entertaining channel. But how does Antena 3 perform in these dimensions? The mean value for the variables Original, Entertaining and Varied in contents constructed from the items in Table 1 are 3.10,3.42 and 3.48. This indicates that Antena 3 is considered by the audience more as an entertaining and content varied channel than as an original channel. These results are very similar to those obtained from a comparative perspective by Centro de Investigaciones Sociológicas (2010). In this study $26.7 \%$ of the respondents thought Antena 3 was one of the two most entertaining television channels in Spain; 26.3\% was one of the two most varied and only the $19.7 \%$ thought it was one of the most original. Therefore, Antena 3 seems to be well positioned in entertainment and variety but would benefit from some improvement in originality, without compromising its good scores in the former dimensions. As usual, there are some limitations in the paper. They have to do mostly with the sample and the context of the empirical analysis. In order to generalize our results, more empirical analyses with samples from different geographical locations are needed. In addition, the evaluation of television quality has been applied to a channel with some specific features. The question remains whether the results would be the same if a different channel had been considered. For example, the patterns through which viewers assess the quality of a channel may depend on their private and public nature. Therefore, future research should be aimed at studying the issue for other television channels, especially public ones.

Furthermore, the non-longitudinal nature of the data does not allow us to definitively establish that the statistical relationships found in the paper are of causality 
in the intended direction. For example, from our findings we cannot discard completely that there is a causal direction from the overall perceived quality of the channel to the different dimensions of quality or to the perceived quality of the genre because of the existence of halo effects. The assessment of this point would require the collection of longitudinal data.

\section{References}

Aguilar-Paredes, C., Gómez-Domínguez, P., Villanueva-Baselga, S., \& Sánchez-Gómez, L. (2016). Propuesta de un índice de la calidad informativa de los telenoticias de las televisiones autonómicas españolas [A proposal for an index to measure the informative quality of the news services of regional televisión channels in Spain]. El profesional de la información, 25 (1), 75-87. doi: 10.3145/epi.2016.ene.08

Ahlers, D. (2006). News consumption and the new electronic media. Harvard International Journal of Press and Politics, 11(1), 29-52. doi: $10.1177 / 1081180 X 05284317$

Artero, J.P., Etayo, C., \& Sánchez-Tabernero, A. (2015). The evolution of viewers' concerns and perceptions of television content quality. Journal of Media Business Studies, 12(4), 205-223. doi: 10.1080/16522354.2015.1099274

Artero, J.P., Etayo, C., \& Sánchez-Tabernero, A. (2016). How advertising affects quality perception of public service television? A comparison of two surveys in Spain (2008 and 2012). Creative Industries Journal, 9(2), 107-115. doi: $10.1080 / 17510694.2016 .1206356$

Bartsch, A. (2012). Emotional gratification in entertainment experience. Why viewers of moves and television series find it rewarding to experience emotions. Media Psychology, 15(3), 267-302. doi: 10.1080/15213269.2012.693811 
Bayo-Moriones, A., Etayo, C., \& Sánchez-Tabernero, A. (2015). Political orientation and perceived quality of television channels. Journal of Service Theory and Practice, 25(6), 813-835. doi: 10.1108/JSTP-09-2014-0217

Berné-Manero, C., García_Uceda, E., \& Orive-Serrano, V. (2013). Understanding the consumption of television programming: development and validation of a structural model for quality, satisfaction and audience behavior. International Journal of Marketing Studies, 5(1), 142-156. doi: 10.5539/ijms.v5n1p142

Blumler, J. B. (ed.) (1991). Broadcasting Finance in Transition: A Comparative Handbook. Oxford: Oxford University Press.

Bottomley, A.J. (2015). Quality TV and the branding of U.S: network television: marketing and promoting Friday Last Nights. Quarterly Review of Film and Video, 32(5), 482-497. doi: 10.1080/10509208.2015.1031624

Broadcasting Research Unit (1989). Quality in Television: Programmes, Programme makers, Systems. London/Paris: John Libbey Media.

Caffarel, C. (2005). ¿Es posible una televisión de calidad? [Is quality television possible?] Comunicar, 25, 23-27.

Camacho, R. (2005). Televisión de calidad: distinción y audiencia [Quality television: distinction and audience]. Comunicar, 25, 29-32.

Centro de Investigaciones Sociológicas (2010). Barómetro de mayo [May barometer]. Madrid: Centro de Investigaciones Sociológicas.

Chan-Olmsted, S., \& Kim, Y. (2001). Perceptions of branding among television station managers: An exploratory analysis. Journal of Broadcasting \& Electronic Media, 45(1), 75-91. doi: 10.1207/s15506878jobem4501_6

Chan-Olmsted, S., \& Kim, Y. (2002). The PBS brand versus cable brands: Assessing the brand image of public television in a multichannel environment. Journal of 
Broadcasting and Electronic Media, 46(2), 300-320. doi: 10.1207/s15506878jobem4602_8

Chrzan, K. and Golovashkina, N. (2006). An empirical test of six stated importance measures. International Journal of Market Research, 48(6), 717-740.

Chu, R. (2002). Stated-importance versus derived-importance customer satisfaction measurement. Journal of Services Marketing, 16(4), 285-301. doi: $10.1108 / 08876040210433202$

Claussen, D. S. (2004). Cognitive dissonance, media illiteracy, and public opinion on news media. American Behavioral Scientist, 48(2), 212-218. doi: $10.1177 / 0002764204267265$

Connolly, S., Hanretty, C., Hargreaves Heap, S., \& Street, J. (2015). What makes for prize-winning television? European Journal of Communication, 30(3), 267-284. doi: $10.1177 / 0267323115577304$

Costera Meijer, I. (2003). What is quality television news? A plea for extending the professional repertoire of newsmakers. Journalism Studies, 4(1), 15-29. doi: $10.1080 / 14616700306496$

Crosby, P. (1979). Quality is Free. New York: McGraw-Hill.

Cummins, R.G., \& Chambers, T. (2011). How production value impacts perceived technical quality, credibility, and economic value of video news. Journalism \& Mass Communication Quarterly, 88(4), 737-752. doi: $10.1177 / 107769901108800404$

Dalton, D., \& Ortegren, M. (2011). Gender differences in ethics research: The importance of controlling for the social desirability response bias. Journal of Business Ethics, 103(1), 73-93. doi: 10.1007/s10551-011-0843-8 
De Jong, M. G., Pieters, R., \& Fox, J. P. (2010). Reducing social desirability through item randomized response: An application to measure underreported desires. Journal of Marketing Research, 47(1), 14-27. doi: 10.1509/jmkr.47.1.14

Del Valle, J.C. (2005). La calidad de la producción audiovisual desde el análisis del valor [The quality of audiovisual production from value analysis]. Comunicar, 25, 1-10.

Dhoest, A. (2014). It's not HBO, it's TV: the view of critics and producers on Flemish 'quality TV'. Critical Studies in Television, 9(1), 1-22. doi: 10.7227/CST.91.1.2

García-Santamaría, J.V., Pérez-Serrano, M.J. \& Alcolea-Díaz, G. (2014). New television platforms in Spain and their influence on the market. Revista Latina de Comunicación Social, 69, 390-417. doi: 10.4185/RLCS-2014-1017en

González-Gorosarri, M. (2017). Objetividad no es neutralidad: la norma objetiva como método periodístico [Objectivity is not neutrality: the objectivity norm as the journalistic method]. Estudios sobre el Mensaje Periodístico, 23(2), 829-846. doi: 10.5209/ESMP.58018

Guerrero, E. \& Etayo, C. (2015). Percepción de calidad de los programas de entretenimiento televisivos en España: influencia de los valores de producción [Quality perception of entertainment TV shows in Spain: production values]. El profesional de la información, 24(3), 256-264. doi: 10.3145/epi.2015.may.05

Guo; M., \& Chan-Olmsted, S.M. (2015). Predictors of social television viewing: How perceived program, media, and audience characteristics affect social engagement with television programming. Journal of Broadcasting \& Electronic Media 59(2), 240-258. doi: 10.1080/08838151.2015.1029122

Gutiérrez, C. (2000). Televisión y calidad: perspectivas de investigación y criterios de evaluación [Television and quality: research perspectives and assessment criteria]. ZER. Revista de Estudios de Comunicación, 9, 1-20. 
Haber, S. and Lerner, M. (1999). Correlates of tourist satisfaction. Annals of Tourism Research, 26(1), 197-201.

Hampton, M. (2008). The 'objectivity' ideal and its limitations in $20^{\text {th }}$-century British journalism”. Journalism Studies, 9(4), 473-493. doi: 10.1080/14616700802113060

Heinderyckx, F. (2006). A composite approach to evaluating the 'quality' of public service broadcasters. RIPE@2006 conference, Amsterdam.

Huang, R. and Sarigöllü (2008). Assessing satisfaction with core and secondary attributes. Journal of Business Research, 61(9), doi: 942-949. 10.1016/j.jbusres.2007.10.003

InfoAdex (2015). Estudio sobre la inversion publicitaria en España [Report about Spanish Advertising Expenditure]. Madrid: InfoAdex.

Ishikawa, S. (ed.) (1996). Quality Assessment of Television. London: University of Luton Press.

Jardine, B., Romaniuk, J., Dawes, J.G., \& Beal, V. (2016). Retaining the primetime television audience. European Journal of Marketing, 50(7-8), 1290-1307. doi: 10.1108/EJM-03-2015-0137

Kantar Media (2013). Anuario de audiencia de televisión [Audience Television Yearbook]. Madrid: Kantar Media.

Kantar Media (2015). Anuario de audiencia de televisión [Audience Television Yearbook]. Madrid: Kantar Media.

Kozak, M. (2001). Repeaters' behavior at two distinct destinations. Annals of Tourism Research, 28(3), 784-807. doi: 10.1016/S0160-7383(00)00078-5

Leggatt, T. (1996). Quality in television: The views from professionals. In S. Ishikawa (ed), Quality Assessment in Programming (pp. 145-168). Luton: John Libbey Media. 
Liu, Y., Putler, D. S., \& Weinberg, C. B. (2004). Is having more channels really better? A model of competition among commercial television broadcasters. Marketing Science, 23(1), 120-133.

Lu, X., \& Lo, H. (2007). Television audience satisfaction: Antecedents and consequences. Journal of Advertising Research, 47(3), 354-363. doi: $10.2501 / \mathrm{S} 0021849907070365$

McQuail, D. (1992). Media Performance. London: Sage.

Mikulic, J., Kresic, D., Prebezac, D., Milicevic, K. and Seric, M. (2016). Identifying drivers if destination attractiveness in a competitive environment: A comparison of approaches. Journal of Destination Marketing and Management, 5(2), 154-163. doi: 10.1016/j.jdmm.2015.12.003

Murschetz, P. (2002). Public service television at the digital crossroads- the case of Austria. International Journal on Media Management, 4(2), 85-94. doi: $10.1080 / 14241270209389985$

Owen, B. M., \& Wildman, S. S. (1992). Video Economics. London: Harvard University Press.

Park, S. (2005). Competition's effects on programming diversity of different program types. International Journal on Media Management, 7(1-2), 39-54. doi: $10.1080 / 14241277.2005 .9669415$

Patterson, T.E. (2000). Doing well and doing good: How soft news and critical journalism are shrinking the news audience and weakening democracy - and what news outlets can do about it. Cambridge: Harvard University Press.

Peitz, M., \& Valletti, T. M. (2008). Content and advertising in the media: Pay-TV versus free to air. International Journal of Industrial Organization, 26(4), 949-965. doi: 10.1016/j.ijindorg.2007.08.003 
Phalen, P. F., \& Ducey, R. V. (2012). Audience behavior in the multi-screen "videoverse". International Journal on Media Management, 14(2), 141-156. doi: $10.1080 / 14241277.2012 .657811$

Pujadas, E., \& Oliva, M. (2007). Evaluating the Diversity of Television Programming. Quaderns del CAC, 28, 81-92.

Samaniego, C. M., \& Pascual, A. C. (2007). The teaching and learning of values through television. Review of Education, 53(1), 5-21. doi: 10.1007/s11159-006-9028-6

Shamir, J. (2007). Quality assessment of television programs in Israel: Can viewers recognize production value? Journal of Applied Communication Research, 35(3), 320-341. doi: 10.1080/00909880701434406

Singhal, A., \& Rogers, E. M. (2002). A theoretical agenda for entertainment-education. Communication Theory, 12(2), 117-135. doi: 10.1111/j.1468-2885.2002.tb00262.x

Tannenbaum, P. H. (2014). The Entertainment Function of Television. New York: Psychology Press.

Thompson, R. J. (1997). Television's Second Gold Age. Syracuse: Syracuse University Press.

Vallejo, F.A., \& Villena, A. (2015). 'La audiencia no lo es todo'. Cuota de pantalla frente a calidad percibida: una propuesta metodológica ['Questioning audience data'. TV share vs. viewers' evaluation: a methodological proposal]. Estudios sobre el Mensaje Periodístico, 21(2), 1275-1293. doi: 10.5209/revESMP.2015.v21.n2.50915

Van der Wurff, R. (2004). Program choices of multichannel broadcasters and diversity of program supply in the Netherlands. Journal of Broadcasting and Electronic Media, 48(1), 134-150. doi: 10.1207/s15506878jobem4801_7 
Vila, N., \& Küster, I. (2014). Public versus private broadcasters' management. Management Decision, 52(8), 1368-1389. doi: 10.1108/MD-05-2013-0295

Von-Rimscha, M.B., De-Acevedo, M., \& Siegert, G. (2010). Securing quality in public service television entertainment. Studies in Communication Sciences, 10(2), 39-57. doi: $10.5167 /$ uzh-38884

Vorderer, P., Klimmt, C., \& Ritterfeld, U. (2004). Enjoyment: At the heart of media entertainment. Communication Theory, 14(4), 388-408. doi: 10.1111/j.14682885.2004.tb00321.x

Westerstahl, J. (1983). Objective new reporting: general premises. Communication Research, 10(3), 403-424. doi: 10.1177/009365083010003007

Wildman, S.S: and Owen, B. (1985). Program competition, diversity and multichannel bundling in the new video industry. In E.M. Noam (ed.), Video media competition: regulation, economics and technology (pp. 244-279). New York: Columbia University Press.

Wober, J. M. (1990). The Assessment of Television Quality. London: IBA Research Paper.

Zaller, J. (2003). A new standard of news quality: Burglar alarms for the monitorial citizen. Political Communication, 20(2), 109-130. doi: $10.1080 / 10584600390211136$ 
Table 1. Items used to measure the assessment of factors associated with quality television on Antena 3

\begin{tabular}{|c|c|}
\hline $\begin{array}{l}\text { Variable } \\
\text { (Cronbach's } \\
\text { alpha) }\end{array}$ & Item \\
\hline \multirow{12}{*}{$\begin{array}{l}\text { Informative } \\
\text { (0.921) }\end{array}$} & News is tackled from different points of view. \\
\hline & It keeps you well informed. \\
\hline & It is neutral in the news coverage. \\
\hline & It is respectful with all political, religious and lifestyle positions. \\
\hline & It is balanced in the treatment of controversial topics. \\
\hline & It is an objective channel. \\
\hline & It offers truthful information. \\
\hline & It reflects diversity of opinion and beliefs in its contents. \\
\hline & It is a channel independent of economic and political power. \\
\hline & It is varied in the ideological approximation to topics. \\
\hline & Its programs guarantee diversity of ideas. \\
\hline & It is a rigorous channel. \\
\hline \multirow{6}{*}{$\begin{array}{l}\text { Entertaining } \\
(0.918)\end{array}$} & It is funny. \\
\hline & It is entertaining. \\
\hline & I enjoy the programs. \\
\hline & I have a good time when I watch Antena 3. \\
\hline & Watching Antena 3 programs, time goes quickly. \\
\hline & The programs are interesting. \\
\hline \multirow{5}{*}{$\begin{array}{l}\text { Educational } \\
(0.806)\end{array}$} & It helps me learn new things. \\
\hline & It is educational. \\
\hline & It broadcasts arts (music, theatre, etc.) of recognized quality. \\
\hline & It helps me widen my perspectives on topics. \\
\hline & It promotes culture. \\
\hline \multirow{4}{*}{$\begin{array}{l}\text { Desirable } \\
\text { values (0.864) }\end{array}$} & There is a lot of violence in its programs $(\mathrm{R})$. \\
\hline & There is a lot of sex in its programs $(\mathrm{R})$. \\
\hline & It has offensive and rough contents (R). \\
\hline & It is a disgusting channel (R). \\
\hline
\end{tabular}




\begin{tabular}{|c|c|}
\hline & It is frivolous in its values $(\mathrm{R})$. \\
\hline \multirow{4}{*}{$\begin{array}{l}\text { Varied in } \\
\text { contents } \\
(0.836)\end{array}$} & It is varied in the type of programs broadcasted. \\
\hline & It contains programs for all tastes and types of viewers. \\
\hline & It offers very diverse programs. \\
\hline & The program scheduling is very diverse. \\
\hline \multirow{5}{*}{$\begin{array}{l}\text { Social } \\
\text { commitment } \\
(0.807)\end{array}$} & It is social interest channel. \\
\hline & It does a social service to society. \\
\hline & It offers a wide coverage of the main debates in Spanish society. \\
\hline & Its program scheduling adequately reflects the problems in our society. \\
\hline & It broadcasts the main events of general interest in our country. \\
\hline \multirow{6}{*}{$\begin{array}{l}\text { Original } \\
(0.843)\end{array}$} & It is an innovative channel. \\
\hline & $\begin{array}{l}\text { It does not repeat already known formulae, but explores new types of } \\
\text { programs. }\end{array}$ \\
\hline & It takes risks in the new programs launched. \\
\hline & It attempts to surprise the viewer. \\
\hline & The programs are very creative. \\
\hline & It is original \\
\hline \multirow{4}{*}{$\begin{array}{l}\text { Good technical } \\
\text { quality (0.711) }\end{array}$} & There are hardly any technical mistakes in their programs. \\
\hline & It has very good professionals. \\
\hline & The stars of the channel (program presenters, etc.) are very good. \\
\hline & The technical quality of the programs is excellent. \\
\hline \multirow{4}{*}{$\begin{array}{l}\text { Protective of } \\
\text { Spanish culture } \\
(0.883)\end{array}$} & Spanish traditions are present in the program scheduling. \\
\hline & It is a channel that respects and promotes Spanish culture. \\
\hline & It is a channel that contributes to the development of Spanish culture. \\
\hline & It favours and stimulates the manifestations of Spanish culture. \\
\hline \multirow{5}{*}{$\begin{array}{l}\text { Adjusts to my } \\
\text { preferences } \\
\text { and } \\
\text { opinions }(0.883)\end{array}$} & It offers what I look for in a television channel \\
\hline & I agree with the values and opinions it conveys. \\
\hline & It is a close and familiar channel. \\
\hline & It offers the type of programs I am interested in. \\
\hline & It coincides with my opinions and personal values. \\
\hline
\end{tabular}


Table 2. Distribution of frequencies of ranking of factors according to their importance in defining quality television

\begin{tabular}{|c|c|c|c|c|c|c|c|c|c|c|c|}
\hline & Informative & Entertaining & Educational & $\begin{array}{c}\text { Desirable } \\
\text { values }\end{array}$ & $\begin{array}{c}\text { Varied } \\
\text { in } \\
\text { contents }\end{array}$ & $\begin{array}{c}\text { Committed } \\
\text { to society }\end{array}$ & Original & $\begin{array}{c}\text { Technical } \\
\text { quality }\end{array}$ & $\begin{array}{c}\text { Protective } \\
\text { of } \\
\text { Spanish } \\
\text { culture }\end{array}$ & \begin{tabular}{|c|} 
Adjustment \\
to my \\
preferences \\
and \\
opinions
\end{tabular} & \\
\hline $\begin{array}{r}10 \text { (most } \\
\text { important) }\end{array}$ & $28.6 \%$ & $18 \%$ & $11.4 \%$ & $10.9 \%$ & $4.7 \%$ & $5.9 \%$ & $6.4 \%$ & $1.5 \%$ & $2 \%$ & $10.9 \%$ & 100 \\
\hline 9 & $13.1 \%$ & $13.8 \%$ & $15.3 \%$ & $12.1 \%$ & $7.4 \%$ & $13.3 \%$ & $8.6 \%$ & $3.2 \%$ & $4.7 \%$ & $8.4 \%$ & 100 \\
\hline 8 & $13.8 \%$ & $12.6 \%$ & $16 \%$ & $9.4 \%$ & $8.4 \%$ & $9.1 \%$ & $11.6 \%$ & $5.7 \%$ & $5.7 \%$ & $7.7 \%$ & 100 \\
\hline 7 & $9.9 \%$ & $12.1 \%$ & $10.4 \%$ & $10.1 \%$ & $14.8 \%$ & $9.9 \%$ & $14.3 \%$ & $7.4 \%$ & $4.2 \%$ & $6.9 \%$ & 100 \\
\hline 6 & $8.9 \%$ & $11.6 \%$ & $10.1 \%$ & $11.9 \%$ & $12.8 \%$ & $7.4 \%$ & $12.3 \%$ & $10.1 \%$ & $8.4 \%$ & $6.4 \%$ & 100 \\
\hline 5 & $6.9 \%$ & $9.9 \%$ & $10.4 \%$ & $12.3 \%$ & $10.1 \%$ & $11.9 \%$ & $14.1 \%$ & $10.1 \%$ & $7.9 \%$ & $6.4 \%$ & 100 \\
\hline 4 & $8.1 \%$ & $7.7 \%$ & $12.8 \%$ & $9.6 \%$ & $12.8 \%$ & $11.9 \%$ & $10.9 \%$ & $9.1 \%$ & $6.7 \%$ & $10.4 \%$ & 100 \\
\hline 3 & $5.4 \%$ & $8.4 \%$ & $7.4 \%$ & $8.1 \%$ & $11.1 \%$ & $14.8 \%$ & $8.1 \%$ & $12.8 \%$ & $12.3 \%$ & $11.4 \%$ & 100 \\
\hline 2 & $3.2 \%$ & $3.7 \%$ & $4 \%$ & $9.6 \%$ & $11.1 \%$ & $9.4 \%$ & $8.6 \%$ & $17.8 \%$ & $21.2 \%$ & $11.4 \%$ & 100 \\
\hline $\begin{array}{r}1 \text { (least } \\
\text { important) }\end{array}$ & $2 \%$ & $2.2 \%$ & $2.2 \%$ & $5.9 \%$ & $6.9 \%$ & $6.4 \%$ & $4.9 \%$ & $22.2 \%$ & $26.9 \%$ & $20.2 \%$ & 100 \\
\hline Mean & 7.291 & 6.746 & 6.486 & 5.844 & 5.235 & 5.422 & 5.696 & 3.852 & 3.598 & 4.830 & \\
\hline
\end{tabular}


Table 3. The influence of the assessment of quality dimensions in global quality assessment

\begin{tabular}{|c|c|c|}
\hline & OLS & $\begin{array}{c}\text { Ordered } \\
\text { logit }\end{array}$ \\
\hline Informative & $\begin{array}{l}.078 \\
(.083)\end{array}$ & $\begin{array}{l}.300 \\
(.233)\end{array}$ \\
\hline Entertaining & $\begin{array}{l}.464 * * * \\
(.120)\end{array}$ & $\begin{array}{c}1.361 * * * \\
(.347)\end{array}$ \\
\hline Educational & $\begin{array}{l}.056 \\
(.068)\end{array}$ & $\begin{array}{l}.211 \\
(.193)\end{array}$ \\
\hline Desirable values & $\begin{array}{l}-.024 \\
(.053)\end{array}$ & $\begin{array}{c}-.084 \\
(.0328)\end{array}$ \\
\hline Varied in contents & $\begin{array}{l}.169 * * \\
(.072)\end{array}$ & $\begin{array}{l}.489 * * \\
(.204)\end{array}$ \\
\hline Committed to society & $\begin{array}{l}-.078 \\
(.072)\end{array}$ & $\begin{array}{l}-.230 \\
(.204)\end{array}$ \\
\hline Original & $\begin{array}{l}.158 * * \\
(.073)\end{array}$ & $\begin{array}{l}.395^{*} \\
(.208) \\
\end{array}$ \\
\hline Technical quality & $\begin{array}{c}.051 \\
(.071)\end{array}$ & $\begin{array}{l}.052 \\
(.200)\end{array}$ \\
\hline Protective of Spanish culture & $\begin{array}{l}-.099 \\
(.116)\end{array}$ & $\begin{array}{l}-.227 \\
(.328)\end{array}$ \\
\hline $\begin{array}{l}\text { Adjustment to own preferences and } \\
\text { opinions }\end{array}$ & $\begin{array}{l}.247 * * * \\
(.078)\end{array}$ & $\begin{array}{l}.635^{* * * *} \\
(.223)\end{array}$ \\
\hline Constant & $\begin{array}{l}.305 \\
(.290)\end{array}$ & \\
\hline Cut 1 & & $\begin{array}{c}3.760 * * * \\
(.924)\end{array}$ \\
\hline Cut 2 & & $\begin{array}{c}6.184 * * * \\
(.887)\end{array}$ \\
\hline Cut 3 & & $\begin{array}{c}9.073 * * * \\
(.962)\end{array}$ \\
\hline Cut 4 & & $\begin{array}{c}11.700^{* * *} \\
(1.073)\end{array}$ \\
\hline F / Chi-2 test & $29.79 * * *$ & $217.52 * * *$ \\
\hline $\mathbf{R}^{2} /$ Pseudo $\mathbf{R}^{2}$ & 45.7 & 48.4 \\
\hline
\end{tabular}

$* * * \mathrm{p}<0.01, * * \mathrm{p}<0.05, * \mathrm{p}<0.1$ 
Table 4. The influence of the perceived quality of the genres in overall quality assessment of the channel

\begin{tabular}{|c|c|c|}
\hline & OLS & $\begin{array}{c}\text { Ordered } \\
\text { logit }\end{array}$ \\
\hline News & $\begin{array}{c}.274 * * * \\
(.064)\end{array}$ & $\begin{array}{c}.642^{* * *} \\
(.159)\end{array}$ \\
\hline Magazines and talk shows & $\begin{array}{l}.124 * * \\
(.061)\end{array}$ & $\begin{array}{l}.298 * * \\
(.148)\end{array}$ \\
\hline Movies & $\begin{array}{l}.127 * * \\
(.064)\end{array}$ & $\begin{array}{l}.326^{* *} \\
(.156)\end{array}$ \\
\hline Fiction television series & $\begin{array}{c}.078 \\
(.064)\end{array}$ & $\begin{array}{l}.196 \\
(.166)\end{array}$ \\
\hline Game shows & $\begin{array}{l}.115^{*} \\
(.060)\end{array}$ & $\begin{array}{l}.273^{*} \\
(.145)\end{array}$ \\
\hline Sports & $\begin{array}{l}.143 * * \\
(.061)\end{array}$ & $\begin{array}{l}.407 * * \\
(.151)\end{array}$ \\
\hline Documentaries & $\begin{array}{l}-.055 \\
(.065)\end{array}$ & $\begin{array}{l}-.129 \\
(.158)\end{array}$ \\
\hline Reality television & $\begin{array}{l}.129 * * \\
(.052)\end{array}$ & $\begin{array}{l}.311^{* *} \\
(.130)\end{array}$ \\
\hline Music and talent search & $\begin{array}{c}.002 \\
(.058)\end{array}$ & $\begin{array}{l}-.025 \\
(.140)\end{array}$ \\
\hline Entertainment and humour & $\begin{array}{l}-.006 \\
(.061)\end{array}$ & $\begin{array}{l}.001 \\
(.148)\end{array}$ \\
\hline Education \&information & $\begin{array}{c}.026 \\
(.063)\end{array}$ & $\begin{array}{l}.095 \\
(.151)\end{array}$ \\
\hline Docufiction & $\begin{array}{l}.014 \\
(.064)\end{array}$ & $\begin{array}{l}.024 \\
(.155)\end{array}$ \\
\hline Constant & $\begin{array}{c}.465 \\
(.353)\end{array}$ & \\
\hline Cut 1 & & $\begin{array}{c}2.963 * * * \\
(.982)\end{array}$ \\
\hline Cut 2 & & $\begin{array}{c}5.106^{* * * *} \\
(.934)\end{array}$ \\
\hline Cut 3 & & $\begin{array}{c}7.633 * * * \\
(1.011)\end{array}$ \\
\hline Cut 4 & & $\begin{array}{c}9.759 * * * \\
(1.073)\end{array}$ \\
\hline F / Chi-2 test & $9.72 * * *$ & $91.95 * * *$ \\
\hline $\mathbf{R}^{2} /$ Pseudo $\mathbf{R}^{2}$ & 34.4 & 34.9 \\
\hline
\end{tabular}

$* * * \mathrm{p}<0.01, * * \mathrm{p}<0.05, * \mathrm{p}<0.1$ 